\title{
Finite element analysis of the effect $M / V$ ratios on punching shear strength of edge slab- column connections of flat plate structure
}

\author{
I Ketut Sudarsana ${ }^{1}$, I Gede Gegiranang Wiryadi2,, ${ }^{2}$, and I Gede Adi Susila ${ }^{1}$ \\ ${ }^{1}$ Department of Civil Engineering, Universitas Udayana, Denpasar, Indonesia \\ ${ }^{2}$ Department of Civil Engineering, Universitas Mahasaraswati Denpasar, Denpasar, Indonesia
}

\begin{abstract}
The occurrence of unbalanced moment in edge slab-column connections of flat plate structure cannot be avoided and increase the slab shear stress around the column. This paper investigates the effect of $\mathrm{M} / \mathrm{V}$ ratio on punching shear strength of edge column-slab connections using finite element analysis. The Concrete Damage Plasticity (CDP) and truss model in Abaqus were used to model the nonlinear behavior of concrete and reinforcement, respectively. Ten values of the $\mathrm{M} / \mathrm{V}$ ratio were applied to a subassembly edge connection model which was part of a properly design of a 5 story flat plate structure. The shear strength prediction of ACI 318-14 code on the effect of unbalanced moment in edge column-slab connection was also studied. The analysis results show that the effect of unbalanced moment on shear strength is not significant for $\mathrm{M} / \mathrm{V}$ ratio less than 0.3 . However, for $\mathrm{M} / \mathrm{V}$ ratio greater than 0.3 , the shear strength is reduced in an exponential order. The ACI 318-14 code overestimates prediction on connection's shear strength for the $\mathrm{M} / \mathrm{V}$ ratio less than 0.3 . The code predictions are in a good agreement with the analysis results for the edge connection with the $\mathrm{M} / \mathrm{V}$ ratio greater than 0.3 .
\end{abstract}

\section{Introduction}

The existence of an unbalance moment in slab-column connections of flat plate structures due to span differences, uneven gravity load distribution and lateral loads (i.e., wind and earthquake loads) cannot be avoided especially in edge column-slab connections. This moment can affect the punching shear capacity of the connections. The unbalance moment $(\mathrm{Mu})$ and shear force $(\mathrm{Vu})$ act together to produce punching shear stress at the critical section which is defined at $\mathrm{d} / 2$ away from column faces [1]. ACI 318 [1] defines that $40 \%$ of the unbalance moment is transferred by shear and the rest is transferred by flexure. The magnitude of unbalanced moment acting on the connections varies according to slab adjacent spans, distribution of dead load, the occupancies activity, and magnitude of lateral forces. This condition causes the ratio between unbalance moment and shear force (M/V) changed and affected the punching shear stress at slab critical section. Numerous experimental and numerical studies have been done to investigate the interaction between

\footnotetext{
* Corresponding author: anankwiryadi@ymail.com
} 
unbalance moment and shear force in edge column-slab connections and proposed the interaction models [1-4]. Sudarsana and Gardner [2, 4], shows that a bilinear interaction between unbalance moment and shear force of ACI 318 at edge column slab connections can predict the degree of the interaction for isolated specimens, but it is too conservative for small $\mathrm{M} / \mathrm{V}$ ratio. However, Moehle [3] stated that there is no interaction between the unbalanced moment and shear force on edge slab-column connection. Therefore, the failure of the connections occurred due to shear or flexure strength exceeded. The shear capacity of the connections can be multiplied by 0.67 to account the effect of the unbalanced moment in the connections [2]. The punching failure pattern on the slab around the column is following the direction of unbalance moment [5].

This study investigates the effect of $\mathrm{M} / \mathrm{V}$ ratio on edge slab-column connection with the unbalances moment working perpendicular to the slab free edge. A finite element software Abaqus was used to study the parameter of $\mathrm{M} / \mathrm{V}$ ratio on punching strength of the connections. Concrete Damage Plasticity (CDP) in Abaqus to model the nonlinear characteristic and behavior of concrete give good predictions on the behavior of punching shear when it compares with experiment results [6,7]. The results of the analysis are compared to the ACI 318-14 code prediction.

\section{Analysis method}

\subsection{Code prediction for punching strength}

ACI 318-14 code calculates punching shear stress $\left(V_{u}\right)$ at critical section due to the combination of shear force and unbalances moment using an expression in Eq. 1. A portion of the unbalanced moment to be transferred as shear $\left(\gamma_{v}\right)$, defines using Eq. 3 .

$$
v_{u(A B)}=\frac{V_{u}}{A_{c}} \pm \frac{\gamma_{v} M_{u} c_{A B}}{J_{c}}
$$

Critical section area $\left(\mathrm{A}_{c}\right)$ is calculated according to the critical perimeter $\left(b_{0}\right)$ multiplied by slab effective depth (d) around the column and following Eq. 2 and 3:

$$
A_{c}=b_{0} d
$$

$J_{c}$ is component of critical section which analogues with polar inertia moment and can be calculated following Eq. 5. The Eq. 4 of ACI 318 [1] cannot give accurate results if the column shapes are not nearly square [8], [9].

$$
\begin{gathered}
\gamma_{v}=1-\frac{1}{1+\frac{2}{3} \sqrt{\frac{b_{1}}{b_{2}}}} \\
J_{c}=\frac{\left(c_{1}+d / 2\right)(d)^{3}}{6}+\frac{2(d)}{3}\left(c^{3}{ }_{A B}+c^{3} C D\right)+\left(c_{2}+d\right)(d)\left(c_{A B}\right)^{2}
\end{gathered}
$$

The critical section area $\left(A_{c}\right)$ is determined at a distance of $d / 2$ from column faces on slab around column or load. The shear stress diagram at the critical section can be seen in Fig. 1. 

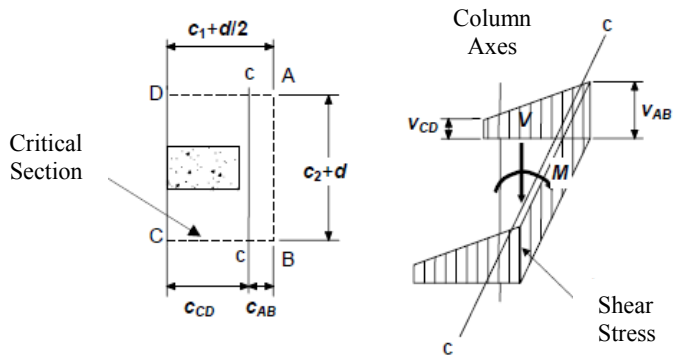

Fig. 1. Stress diagram on critical section.

\subsection{Specimen models}

The specimen models considered in this study are the same properties as in [5]. However, the primary parameter to be studied is $\mathrm{M} / \mathrm{V}$ ratio due to unbalanced moment perpendicular to slab free edge. As many as ten variations of $\mathrm{M} / \mathrm{V}$ ratio were applied such as 0.0 (shear force only), $0.1 \mathrm{~m}, 0.2 \mathrm{~m}, 0.3 \mathrm{~m}, 0.4 \mathrm{~m}, 0.5 \mathrm{~m}, 0.6 \mathrm{~m}, 1.0 \mathrm{~m}$, and $1.4 \mathrm{~m}$ and moment only. The isolated edge column-slab connection is designed to conform to the requirements of [1] and [10]. The arrangement of the slab reinforcement can be seen in Fig. 2(a) and (b). The application of loads and support position are shown in Fig. 2(c). The vertical load and the horizontal loads to produced unbalance moment are applied through the column stubs as shown in Fig. 2(c). All loads are applied simultaneously until the connections fail.

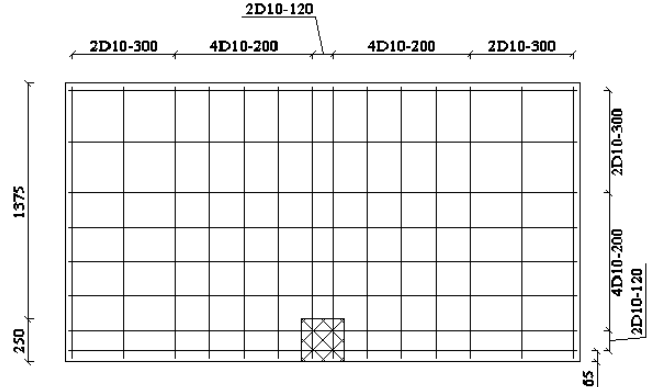

(a)

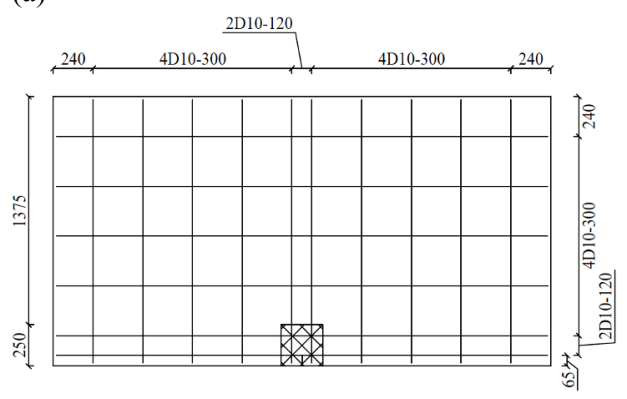

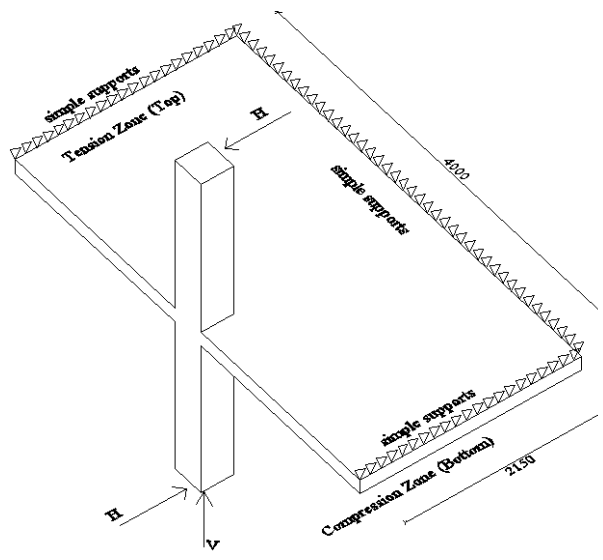

(c)

(b)

Fig. 2. Reinforcement layout and loading scheme (a) top slab rebars, (b) bottom slab rebars, (c) support position and applied loads.

\subsection{FE modelling and material properties}

The RC column-slab connections shown in Fig. 2 were modeled in 3D models using Abaqus software. Material concrete was modeled as 3D-stress element with 8-nodal 
(C3D8R) and reinforcement was modeled as truss-element with 2-nodal (t3d2). Modeling the reinforcement as truss-element or solid-element gives equivalent results [11]. Concrete was assumed to have compressive stress-strain following Hognestad Curve [12]. The nonlinear behavior of concrete was modeled using Concrete Damage Plasticity (CDP) which has CDPs parameters $\left(\psi, \varepsilon, \sigma_{b} / \sigma_{c}, K, \mu\right)$, tensile strain, and use damage mode on strain and compressive behavior. Concrete damage occurred in softening range after peak load in compression and tensile condition. Steel rebar behavior defined using uniaxial strain-stress relation as tabular data yield and ultimate $\left(f_{y}, f_{u}\right)$, Modulus Elasticity $\left(E_{c}\right)$, and poison ratio $(v=0,3)$.

The properties of concrete and steel rebar can be seen in Table 1. In order to have a suitable value of the CDPs parameters $\left(\psi, \varepsilon, \sigma_{b} / \sigma_{c}, K, \mu\right)$, a calibration proses was needed. In this study, a calibration have been done based on one of the experimental results of specimen XXX tested by [13] and have been presented in [14]. It was obtained that the finite element analysis gave good correlation to experimental results for the values of dilatation angle $\psi=40^{\circ}$, eccentricity $\varepsilon_{c}=0.1, K_{c}=2 / 3$, ratio $\sigma_{\mathrm{bo}} / \sigma_{\mathrm{co}}=1.16$, and viscosity parameter $\mu=0.00005$.

Table 1. Property of materials

\begin{tabular}{|c|c|c|c|c|}
\hline \multicolumn{5}{|c|}{ (a) Concrete properties } \\
\hline $\begin{array}{l}\text { Compressive } \\
\text { strength, } f^{\prime} c \\
\text { (MPa) }\end{array}$ & $\begin{array}{l}\text { Tension } \\
\text { strength, } f_{c t} \\
\text { (MPa) }\end{array}$ & $\begin{array}{c}\text { Modulus } \\
\text { Elasticity, } E_{c} \\
(\mathrm{MPa})\end{array}$ & $\begin{array}{l}\text { Strain at peak } \\
\text { compression } \\
\text { stress, } \varepsilon_{c o}\end{array}$ & $\begin{array}{c}\text { Strain at peak } \\
\text { tension stress } \\
\varepsilon_{\tau}\end{array}$ \\
\hline 30 & 1.81 & 25742 & 0.0023 & 0.00007 \\
\hline \multicolumn{5}{|c|}{ (b) Steel rebar properties } \\
\hline $\begin{array}{l}\text { Yield stress, } f_{y} \\
\quad(\mathrm{MPa})\end{array}$ & $\begin{array}{c}\text { Tension } \\
\text { strength, } f_{u} \\
(\mathrm{MPa})\end{array}$ & $\begin{array}{c}\text { Modulus } \\
\text { Elasticity, } E_{s} \\
(\mathrm{MPa})\end{array}$ & $\begin{array}{c}\text { Yield strain } \\
\varepsilon_{y}\end{array}$ & $\begin{array}{c}\text { Ultimate } \\
\text { strain } \\
\varepsilon_{u}\end{array}$ \\
\hline 400 & 600 & 200,000 & 0.002 & 0.1 \\
\hline
\end{tabular}

\section{Results and discussion}

\subsection{Connection's capacity}

The results of FE Analysis for ten variations of M/V ratio are plotted in Fig. 3 in term of shear forces and unbalanced moments. It is well known that the highest shear capacity of the connection is achieved when there is no unbalanced moment exists as can be seen in Fig. 3. The shear force drops significantly with small $\mathrm{M} / \mathrm{V}$ of $0.1 \mathrm{~m}$, and increase with an increase in $\mathrm{M} / \mathrm{V}$ ratio to reach a maximum value at $\mathrm{M} / \mathrm{V}$ of $0.3 \mathrm{~m}$. When the unbalance moment was increased to have $\mathrm{M} / \mathrm{V}$ ratio greater than $0.3 \mathrm{~m}$, the shear forces decrease with an increase in $\mathrm{M} / \mathrm{V}$ ratio. These results show that the unbalanced moment gives significant influence for $\mathrm{M} / \mathrm{V}$ greater than $0.3 \mathrm{~m}$.

Observing the data in Fig. 3, there is no significant interaction between the shear forces and unbalance moments in the connection in which the connection may fail due to an absolute value of shear forces or unbalanced moments have been reached. This interaction agrees with [3]. However, the limiting flexure capacity (Mflex) was defined by the slab nominal moment within the column strip width, while the limiting shear capacity was defined by multiplying the ACI's pure shear strength by a factor of 0.5 . Using a simple multiplier to account for the effect of the unbalanced moment in edge column slab connection has been suggested by [2]. The proposed simple interaction between shear 
forces and unbalanced moments and the ACI 318 interactions at the edge column slab connection were plotted in Fig. 3 together with the FE analysis results.

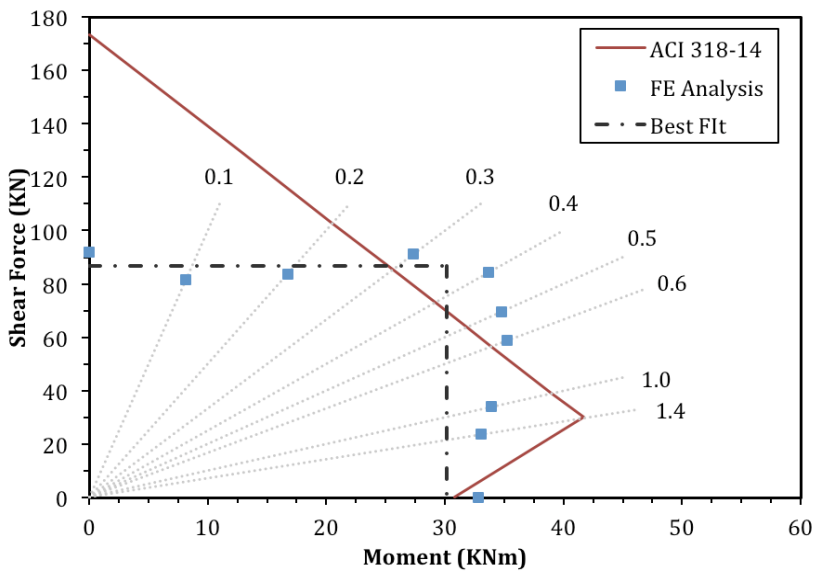

Fig. 3. Interaction diagram of $\mathrm{Vu}-\mathrm{Mu}$.

\subsection{Effect of $M / V$ ratios}

There were ten variations of $\mathrm{M} / \mathrm{V}$ ratio as mention previously. As the connection were loaded simultaneously with a constant $\mathrm{M} / \mathrm{V}$ ratio and it failed at a set combination of shear force and unbalanced moment as can be seen in Table 2 .

Tabel 2. Comparison between ACI predictions with finite element results

\begin{tabular}{|c|c|c|c|c|}
\hline \multirow[b]{2}{*}{$\begin{array}{c}\mathbf{e}=\mathbf{M} / \mathbf{V} \\
(\mathbf{m})\end{array}$} & \multicolumn{2}{|c|}{ FE Analysis } & \multicolumn{2}{|c|}{ ACI 318-14 } \\
\hline & $\begin{array}{c}\text { Shear Force, } \\
\text { V }\end{array}$ & $\begin{array}{c}\text { Unbalanced } \\
\text { Momen, M MEA } \\
\text { (KNm) }\end{array}$ & $\begin{array}{c}\text { Shear Force, } \\
\text { V }_{\text {ACI }}(\mathbf{K N})\end{array}$ & $\begin{array}{c}\text { Unbalanced } \\
\text { Momen, } \mathbf{M}_{\mathrm{ACI}} \\
(\mathrm{KNm})\end{array}$ \\
\hline 0.0 & 91.84 & - & 173.27 & - \\
\hline 0.1 & 81.66 & 8.17 & 128.88 & 12.89 \\
\hline 0.2 & 83.66 & 16.73 & 102.60 & 20.52 \\
\hline 0.3 & 91.08 & 27.33 & 85.22 & 25.57 \\
\hline 0.4 & 84.31 & 33.72 & 72.88 & 29.15 \\
\hline 0.5 & 69.51 & 34.75 & 63.66 & 31.83 \\
\hline 0.6 & 58.81 & 35.28 & 56.51 & 33.90 \\
\hline 1.0 & 33.92 & 33.92 & 38.99 & 38.99 \\
\hline 1.4 & 23.63 & 33.08 & 29.76 & 41.67 \\
\hline$\infty$ & - & 32.86 & - & 30.81 \\
\hline
\end{tabular}


It is shown that for $\mathrm{M} / \mathrm{V}$ ratio less than $0.3 \mathrm{~m}$, there is no significant reduction on shear capacity of the connection except for the connection with pure shear force. For M/V ratio greater than $0.3 \mathrm{~m}$, the shear capacity of the connection decreases as $\mathrm{M} / \mathrm{V}$ ratios increase. Its reduction follows an exponential curve as shown in Fig. 4.

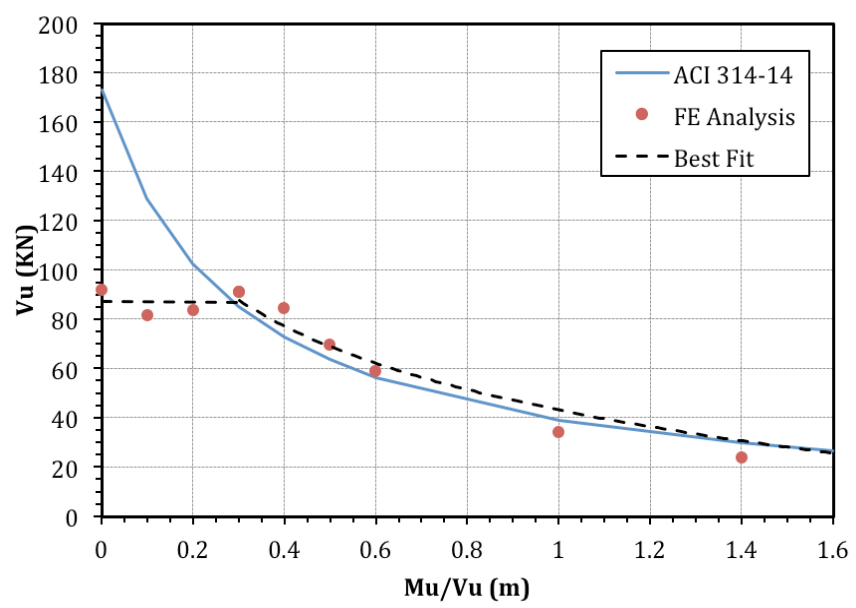

Fig. 4. Relationship between $\mathrm{M} / \mathrm{V}$ ratio and shear force $\left(V_{u}\right)$.

The connection capacity of ACI 318 [1] was also calculated following the Eq.1 with a nominal shear stress limit (vn) at the critical section as given in [1]. The calculation results on the prediction of shear forces and unbalanced moments are given in Table 2. It shows that the existence of unbalanced moment reduces the shear force capacity without considering the value of the $\mathrm{M} / \mathrm{V}$ ratio.

The data presented in Table 2 were plotted into Fig. 4 to evaluate the trend of correlation between $\mathrm{M} / \mathrm{V}$ ratios and shear capacity. ACI prediction overestimates the FEA results for $\mathrm{M} / \mathrm{V}$ ratio less than $0.3 \mathrm{~m}$. However, for the $\mathrm{M} / \mathrm{V}$ ratio greater than 0.3 , the shear forces decrease in an exponential order which is in a good agreement with the ACI 318-14 prediction. Based on FEA results, the best fit curve is suggested that consists of two curves namely a constant line for $\mathrm{M} / \mathrm{V}$ ratio less than $0.3 \mathrm{~m}$ and an exponential curve for $\mathrm{M} / \mathrm{V}$ ratio higher than $0.3 \mathrm{~m}$ as indicated by dotted line in Fig. 4 .

\subsection{Stress and strain of concrete and reinforcement}

The shears stress and strain of RC slab around the column perimeter are presented in this paper. However, only the connections subjected to pure shear force, pure flexure and $\mathrm{M} / \mathrm{V}$ $=0.3 \mathrm{~m}$ are included in this paper due to limited space. Other data can be found in [15]. The stresses in reinforcement at the maximum loads are also presented for all $\mathrm{M} / \mathrm{V}$ ratios.

\subsubsection{Stress and strain in concrete slab}

Principle stress and strain of concrete slab for three $\mathrm{M} / \mathrm{V}$ ratios of $0.0,0.3 \mathrm{~m}$, and $\infty$ are presented in Fig. 5 to 7. It is shown that the maximum principal strain concentrates around column perimeters, however, the maximum principal stress move away from column perimeter with a fan shape. 


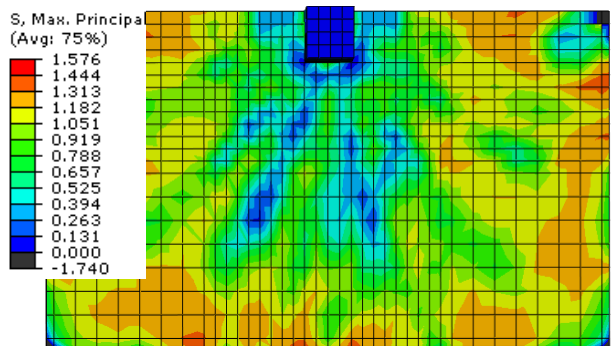

(a)

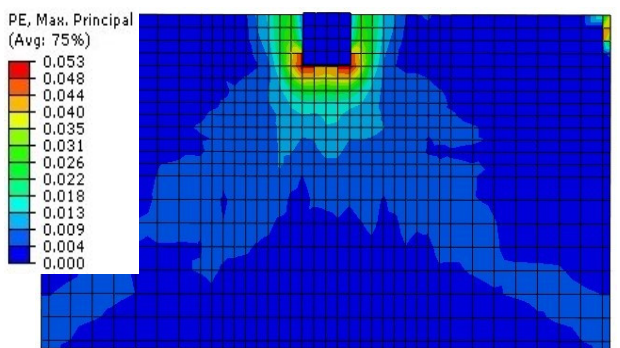

(b)

Fig. 5. Slab principle stress and strain for $M / V=0$, (a) slab principle stress, (b) slab principle strain.

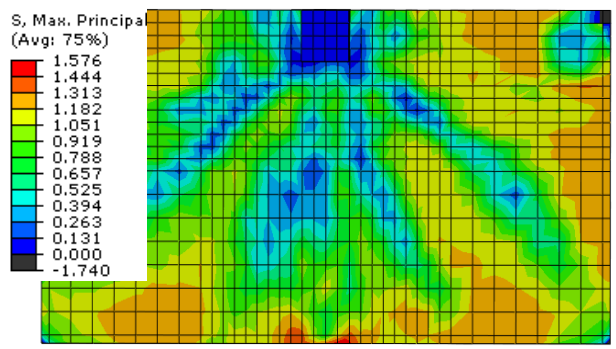

(a)

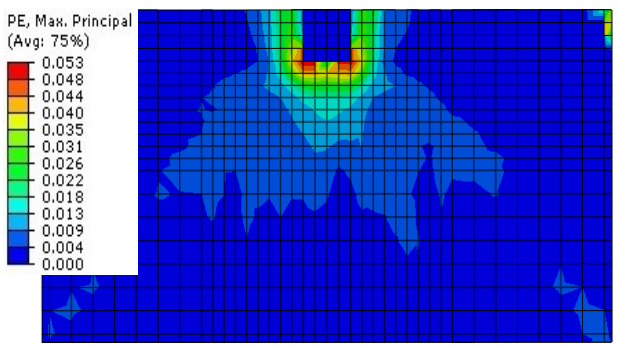

(b)

Fig. 6. Slab principle stress and strain for model $\mathrm{M} / \mathrm{V}=0.3 \mathrm{~m}$, (a) slab principle stress, (b) slab principle strain.

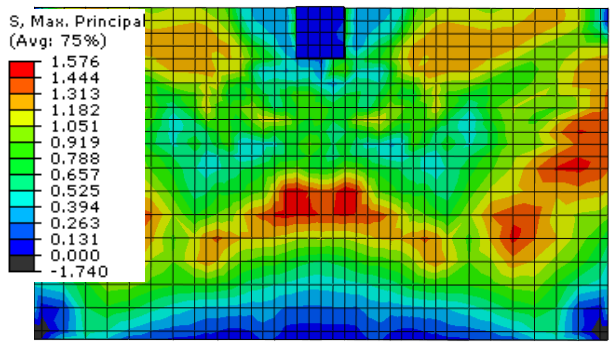

(a)

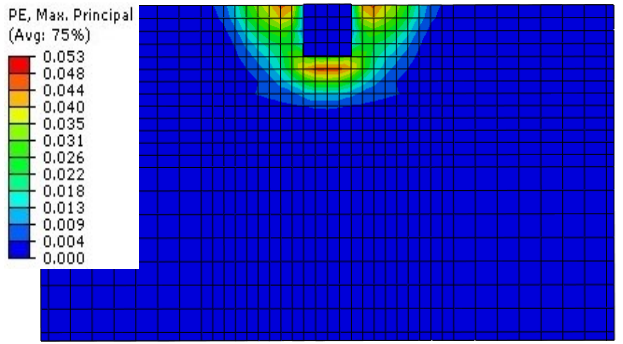

(b)

Fig. 7. Slab principle stress and strain for model $M / V=\infty$, (a) slab principle stress, (b) slab principle strain.

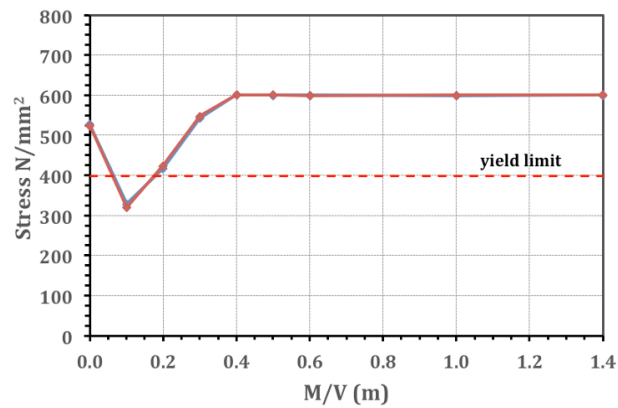

(a)

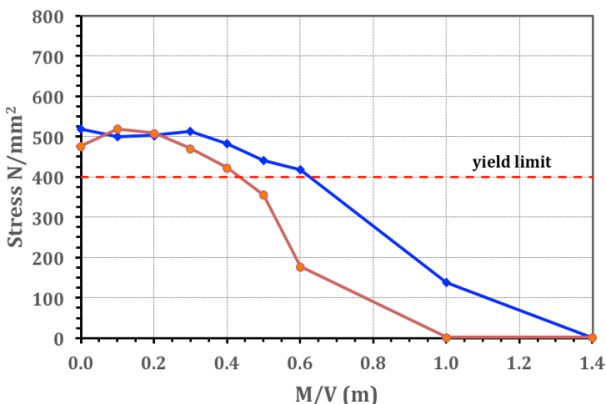

(b)

Fig. 8. Stress on rebars pass through the column faces, (a) rebar perpendicular to free edge, (b) rebar pararel to free edge. 


\subsubsection{Stress in slab reinforcement}

Reinforcement stresses are observed on two rebars passing through the column perpendicular and parallel to free edge on the maximum load. Comparison of all results every specimen can be seen in Fig. 8. All rebar perpendicular to the free edge passed the yield stress limit except rebar in specimen $\mathrm{M} / \mathrm{V}$ ratio $0.1 \mathrm{~m}$. This condition shows the punching shear of slab-column connection is a shear-flexure phenomenon, in which all rebar passing through the column yielded when the connection failure [4]. Rebar parallel to the free edge passed the yield limit stress in the specimen with $\mathrm{M} / \mathrm{V}$ ratio $<0.6 \mathrm{~m}$, while rebar in the specimen with $\mathrm{M} / \mathrm{V}$ ratio greater than $0.6 \mathrm{~m}$ did not reach the yield stress.

\section{Conclusions}

The following conclusions can be drawn from the results of finite element analysis and discussions: 1) Shear force and unbalanced moment perpendicular to slab edge have no significant interaction on the edge column slab connections. The punching failure can occur due to pure shear or pure moment; 2) In the existence of unbalanced moment less than Mflex in the edge column slab connection, the maximum shear capacity can be obtained by multiplying the ACI 318 pure shear force by a factor of 0.5 . The flexure moment (Mflex) is the nominal moment provided by the plate tension rebars perpendicular to slab edge within the column strip; 3 ) The $\mathrm{M} / \mathrm{V}$ ratio less than $0.3 \mathrm{~m}$ does not affect the shear capacity of the connection, and ACI 318-14 overestimates this conditions. However, for the M/V ratios greater than $0.3 \mathrm{~m}$, the ACI 318-14 code in a good agreement with the FE results; 4) The rebars perpendicular to the slab edge and pass through the column faces, yield when connection failure. This indicates the punching shear on edge slab-column connection is a shear-flexure phenomenon.

\section{References}

1. ACI, Building Code Requirements for Structural Concrete ACI 318-14 and Commentary ACI 318R-14 (American Concrete Institute, Farmington Hill, 2014)

2. N.J. Gardner, X.Y. Shao, ACI Struct. J. 93 (1996)

3. J.P. Moehle, ACI Struct. J. 85 (1988)

4. I.K. Sudarsana, A.J. Gardnel, $2^{\text {nd }}$ ACF Conference (2006)

5. I.K. Sudarsana, I.G. Wiryadi, I.G.A Susila, MATEC Web Conf. 159 (2018)

6. A.S. Genikomsou, M.A. Polak, ASCE Structures Congress (2014)

7. A.S. Genikomsou, M.A. Polak, Eng. Struct. 98 (2015)

8. A. Ghali, S. Megally, ACI Struct. J. 96 (1999)

9. A. Ghali, R.B. Gayed, W. Dilger, ACI Struct. J. 112 (2015)

10. Standar Nasional Indonesia, Persyaratan Beton Struktural untuk Bangunan Gedung SNI 2847-2013 (Badan Standardisasi Nasional, Jakarta, 2013)

11. T.S. Viswanathan, G.G. Mohan, A.S. Santhi, Int. J. Civ. Struct. Eng. 2, 3 (2012)

12. E. Hognestad, Univ. Illinois Bull. Ser. 399 (1951)

13. E.F. El-salakawy, M.A. Polak, M.H. Soliman, Can. J. Civ. Eng. 25 (1998)

14. I.K. Sudarsana, I.G.G Wiryadi, I.G.A Susila, J. Spektran. 5, 2 (2017)

15. I.G.G. Wiryadi, Analisis elemen hingga perilaku hubungan pelat-kolom beton bertulang akibat gaya geser dan momen tak imbang dua arah (Thesis, Udayana University, Denpasar, 2017) 